\title{
Procopius's Sibyl - The Fall of Vitigis and the Ostrogoths
}

\section{Tamás Kovács}

(University of Szeged)

\begin{abstract}
The monumental work of Procopius on Justinian's wars includes two Sibylline oracles. As is often the case, the oracles are ambiguous; however, it is precisely this feature that helps to reveal their real meaning. As a consequence, the oracles can also aid researchers in understanding the basis of Byzantine political thought. This essay discusses the connotations of the Sibylline oracle in 537 through classical text analysis, revealing that Procopius used archaic ethnonyms and royal titles to draw a parallel between the fall of the Kingdom of Lydia and the Ostrogothic Kingdom. Using this framework, Procopius stresses that in 410, Alaric committed the original crime by abducting Galla Placidia; however, Vitigis and his wife Matasuntha were the ones who atoned for this sin in 540 .
\end{abstract}

\section{Keywords}

Gothic war; Procopius of Caesarea; Sibyl; Vitigis; Matasuntha 
The first phase of the Gothic War began promisingly in 535. Belisarius captured Sicily within a year, then moved further into Italy the following spring and made his way towards Naples without encountering any significant resistance. Naples fell within a month, which caused disarray between the Goths. Enraged with the inactivity of Theodahad, they gathered in council and elected Vitigis. The followers of the new king killed Theodahad, while Vitigis headed to Ravenna in order to unify his forces. The departure of the Goths gave Belisarius the opportunity to capture Rome, which he took, and thus the returning Vitigis found Roman soldiers in the city in March of 537. According to Procopius, when the siege began, some patricians brought out the Sibylline oracles $(\Sigma\llcorner\beta \dot{v} \lambda \lambda \eta \varsigma$ $\lambda$ ófıa), declaring that the danger of Rome would last until July because the prophecy said: "In the fifth month ... as king nothing Getic longer." ${ }^{1}$ However, Procopius claimed that the patricians misunderstood the prophecy because the danger lasted much longer. Therefore the question is: What is the real meaning of the prophecy?

Each essential word, "Sibyl", "quintilis", and the ethnonym "Getic", shows an archaizing tendency that helps to understand the significance of this oracle in the context of the Wars. Procopius wrote the obviously imperfect Latin text in Greek transliteration, therefore, historians and philologists have deciphered the possible reading of the deficient oracle. ${ }^{2}$ However, far too little attention has been paid to those words that were certain. The aim of this essay is to explore the relationship between these words and reveal the connotations of the oracle through three chapters, each dedicated to one of these words. During the sections, this study will reveal that both the circumstances of the oracle and its words served as an allusion to the Delphic oracle of Croesus; therefore, it foreshadowed that the Gothic realm was going to fall with their fifth monarch due to the sin of an ancestor.

\section{Sibyl}

Our knowledge holds that the Sibyls were an unspecified number of mortal seers in the Greco-Roman world; however, initially both the Greeks and Romans believed that there was only one Sibyl. According to Ovid, Sibyl took a handful of sand and asked Apollo to let her live for as many years as the grains of sand she held. ${ }^{3}$ The grains and thus Sibyl's years counted one thousand, which enabled her to appear at different times and places throughout history. Thereby ancient authors counted her by locations. Pausanias added four, while Varro enumerated ten in all: the Persian, the Libyan, the Delphic, the Cimmerian, the Erythraean, the Samian, the Cumaean, the Hellespontine, the Phrygian, and lastly the Tiburtine Sibyl. ${ }^{4}$ However, in the 5-4th century B.C. the first Greek authors, including Heraclitus, Aristophanes, and Plato, seem to have recognized only one Sibyl. ${ }^{5}$

1 Procop. Goth. 1.24.30: $\theta v \iota v \tau \iota \lambda \iota \mu \varepsilon v \sigma \varepsilon \rho \varepsilon \gamma \varepsilon v ı \eta \iota \lambda \gamma \varepsilon \tau \iota \xi v \mu\llcorner a \mu$.

2 E. g. Bury (1896: pp. 360-361) proposes Quintili mense si regnum stat in urbe nihil Geticum iam (metuat?).

3 Ov. Met. 14.130-153.

4 Paus. 10.12.1-11, Varro's main work the Antiquitates rerum humanarum et divinarum has been lost, but having been quoted by others, like Lactantius (Lactant. Div. Inst. 1.6.).

5 Heraclitus, cited by Plutarch, (Plu. de Pythian oraculis), 6, Aristoph. Peace, 1095, 1116, Pl. Phdr. p. 244 b. 
Similarly to the Greek authors, the compilation of Varro's list emerged from the need to reconstruct the oracles after the devastation of the Libri Sibyllini in 83 BC. Until that year they believed that there was a single Sybil, the Cumean, from whom Tarquinius purchased three volumes. ${ }^{6}$

The roots of the Cumean Sibyl point to the East. Seven years after the conflagration of 83 B.C., the Senate, in order to gather a new set of the oracles, dispatched a commission that begin their work in Erythrae, Asia Minor instead of Cumea. ${ }^{7}$ This starting point was not accidental. According to the later account of Lactantius, only one Sibyl inserted her real name in her verse and predicted that she would be called Erythraean although she was born in Babylon, Persia. ${ }^{8}$ Babylon, however, was under the dominium of the Parthian Empire at this time, while Erythrae was associated with Rome after the death of Attalos III, who bequeathed his kingdom to the Romans in 133 B.C. Therefore, for the senatorial committee, the oldest-known and the only accessible location of Sibyl was Erythrae. According to Pausanias, her original name was Herophile, who appeared in Delphi before the Trojan war and Pythia; therefore, he also called her the Trojan Sibyl. ${ }^{9}$ John the Lydian, a contemporary of Procopius, added that Herophile was the name of the Cumean Sibyl. ${ }^{10}$ It seems that the authors accepted that it was their Sibyl from whom Tarquinius purchased the Libri Sibyllini once she was active in Delphi.

The new collection was a mixture of Greek and Latin text. After Erythrae, where the senatorial committee found one thousand Greek verses, they moved forward towards Sibyl's other purported locations, from Samos to Ilium and Erythrae, and even to Africa, Sicily, and the Graeco-Italian colonies. According to Lactantius, the Senate delegated Publius Gabinius, Marcus Otacilius, and Lucius Valerius to collect approximately a thousand verses in Rome written by private persons because the Senate did not consider it lawful for a private person to inspect the oracles. ${ }^{11}$ Therefore, the collection was turned over to the Quindecemviri, a party patrician board, who expunged certain verses that they perceived to be interpolation. ${ }^{12}$ This new mixed Latin and Greek set of Sibylline verses was housed in the restored Temple of Jupiter until 12 B.C. when Augustus as pontifex maximus relocated them to the temple of Apollo Palatinus on the Palatine Hill. ${ }^{13}$ The new collection of Sibylline verses were still in use at this time; however, with the spread of Christianity, they gradually lost prominence. ${ }^{14}$

6 The story, with some variations, can be found in D.H. 4.62; Gell. 1.19.1; Lactant. Div. Inst. 1.6.10-11; Zonar. 7.11.1.

$7 \quad$ D.H. 4.62 .6$.

8 Lactant. Div. Inst. 1,6.

9 Paus. 10.12.5.

10 Lyd. Mens. $4,47$.

11 Lactant. Div. Inst. 1.6.14; D.H. 4.62.6 (following Varro); Tac. Ann. 6.12.

12 Tac. Ann. 6.12.

13 D.C. 39.15-16; Cic. Fam 1.1.3. For the use and perception of the books under Augustus's reign see Gillmeister (2015: pp. 216-222).

14 For the re-constitute the Libri Sibyllini after the fire in 83 BC, and their subsequent use, the nature of the new collection see Keskiaho (2013: pp. 165-172). 
One of the most notable prophecies of Herophile was that for Helen's sake, the Greeks would capture Troy, and that Homer would write falsehoods. ${ }^{15}$ Labeling of a poet as liar was unprecedented by a seer, but not by other authors. ${ }^{16}$ Plato and Plutarch emphasized the ethical side of these falsehoods. In the Republic, Plato was generally concerned with improper depictions of the gods and heroes' acts because he thought that these depictions were ethically false, ${ }^{17}$ while Plutarch's Moralia separates lies into two categories: The unintentional lies are those statements that the authors do not fabricate, but that they erroneously believe to be true, while the intentional lies are 'l'art pour l'art' because they only give pleasure and gratification without any veracity. ${ }^{18}$ For Plato and Plutarch, the primary example of an ethically false or intentional lie is that told of an act of Zeus, who is weighing Achilles's fates. ${ }^{19}$ This legend appeared first in Homer's Iliad ${ }^{20}$ therefore, the psychostasia/kerostasia could be the first and probably the most significant fabrication of Homer that Herophile foretold.

For the authors after Homer, the weighing of fates is ethically false because each person at birth is assigned to a predetermined lifespan; therefore, a god could not modify anybody's fate or Moirai, and any attempt to break this law is considered intolerable. However, in Homer's Iliad, Zeus simply gives Hector his ker, or death, ${ }^{21}$ when Zeus says, "Let us decide should we save him or let him die at Achilles' hands?"22 Therefore, Zeus performs a common function as a giver of death in Homer's work. Some authors maintained that Zeus's power over the Moirai was based on his paternity. ${ }^{23}$ Others, however, combined necessity and fate in a scheme. According to Plato, the Moirai are the daughters of Ananke, who was thought to be the only force capable of influencing their decisions. Aeschylus claimed that not even Zeus could alter what was ordained ${ }^{24}-$ in the Histories, Zeus's son Apollo, even as the patron of Delphi, could not change the fate that Pythia predicted for Croesus. ${ }^{25}$

In the Wars, Procopius connects the individuals' fates with Sibyl because they emerge through two Sibylian oracles regarding the first phase of the Gothic War. According to Procopius, when Belisarius defeated the Vandals and annexed Africa, Justinian initiated the war to recover Italy. Belisarius sailed over to Sicily, while Mundo began his expedition to occupy the Gothic province of Dalmatia. In 536, Mundo's son Maurikios was on

15 Lactant. Div. Inst. 1.6.9.

16 On lying in poetry see Pratt (1993). Dio Chrysostom was fascinated by Homer's lies about the Trojan War. See Kim (2010: pp. 85-139).

17 Pl. R. 2.376e-3.398b.

18 Plut. Mor. 16a-f.

19 Plut. Mor. 17a-b. According to Plutarch, in Aeschylus' lost tragedy the Psychostasia (Aeschyl. Fr. 279-280a), the fight between Memmon and Achilles was preceded by a weighing of fates.

20 Hom. Il. 22.209-213. Earlier in the Illiad 8.69 ff. Zeus weighs the keres of the Greeks and Trojans.

21 Hom. Il. 22.209, Hom. Od. 11.560.

22 Morrison (1997: p. 287).

23 Hes. Th. 904.

24 A. $\operatorname{Pr}$. 510-518.

25 Hdt. 1.91. 
a scouting expedition with a few men nearby the city where he died during an encounter with a group of Goths. Mundo immediately charged against the enemy, but his efforts ended in a Pyrrhic victory. ${ }^{26}$ According to Procopius, the event reminded the Romans of an earlier oracle of Sibyl that claimed that when Africa was occupied, the world would perish along with its offspring. ${ }^{27}$ The second oracle appeared when the Goths began the siege of Rome in 537. During the siege, patricians brought out the Sibylline oracles and declared that the danger for the city would last only until July, when someone would be appointed as emperor over the Romans. ${ }^{28}$ Therefore each oracle predicted an individual's fate, just as in the case of Herodotus's Histories.

\section{Quintilis}

A misinterpretation that arose from ambiguity is a central element of both oracles. In the case of Mundo, added Procopius, the Romans mistakenly believed that the oracle referred to the whole world because the Mundus ( $\mu v v \delta v \varsigma)$ in Latin means "world",29 while in the case of Belisarius, the Romans believed that the siege would end in the "month of Quintilis" ( $\theta v \iota v \tau \iota \lambda \iota \mu \varepsilon v \sigma \varepsilon)$; however, the siege broke up a year later than predicted..$^{30}$ Moreover, Rome experienced similar perils again during the reign of Totila. The nature of the two misunderstandings is not fundamentally different. First, the Romans wrongly

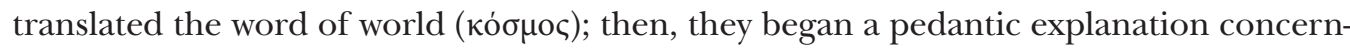
ing the month of Quintilis. They thought that the Quintilis must be July because of the 10-month calendar. ${ }^{31}$ However, when Numa Pompilius promulgated his calendar reform, he introduced the months of January and February. ${ }^{32}$ Therefore the Quintilis became the seventh month but kept its original name until Caesar's reign. These structural modifications were in force by the 6th century; therefore, Procopius emphasized the verbatim

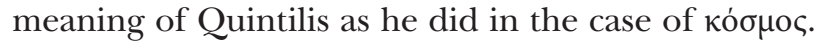

Ordinal numbers often appeared in Roman names; sometimes a person's name was replaced by an ordinal number. The number could indicate either the place of the person in his family's birth order or the person's birth month. In the case of Caesar and Augustus, the Senate used the latter principle; however, the direction was inverse, as the months were given their names after the emperors. While the first four months were already occupied by deities, the fifth month, Quintilis, was renamed by Caesar as Julius, in honor of his birth month. ${ }^{33}$ The September-born Octavius could have used the same

26 Procop. Goth. 1.7.2-6.

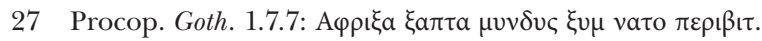

28 Procop. Goth. 1.24.28-30.

29 Procop. Goth. 1.7.8.

30 Procop. Goth. 1.24.28.

31 Procop. Goth. 1.24.31.

32 Liv. 1.19.

33 D. C. $44,5.2$, Suet. Iul. 76.2. 
principle on the ninth month, however he renamed the eighth to August. Furthermore, while Caesar used the nomen gentile, according to Suetonius, Octavius preferred his own cognomen. ${ }^{34}$ He was born into an equestrian branch of the gens Octavia; however, after his adoption, he dropped all reference to his gens. Nonetheless, the Romans colloquially added Octavius to his legal name to differentiate him from Caesar. In 8 B.C., it is possible that this onetime gentile name, at least its ordinal meaning, was preserved in the numerical value of August even though it was hidden behind Octavius' cognomen. Therefore, the renaming of the months could serve as an allusion to a ruler, meaning that it could emphasize the importance of gens and the continuity or even change in a political system.

The fifth king of the Ostrogoths in Italy was Vitigis, whose election and fall closely related to the first phase of the Gothic war. After the fall of Naples, the Goths gathered in council and elected Vitigis as their new king. He immediately left Rome for Ravenna to gather his forces, after which he unsuccessfully attempted to occupy Rome. ${ }^{35}$ In 539, after his failed siege, Vitigis retreated to Ravenna. Believing that the Goths alone were not a match for their enemy in battle, he decided to seek assistance from others. ${ }^{36}$ He called together the elders' council, where somebody suggested that if the Persians were to clash with Justinian, the Romans would never be able to make war against the Goths. In his description of the elders' council, Procopius referred to Chosroes as the king of the

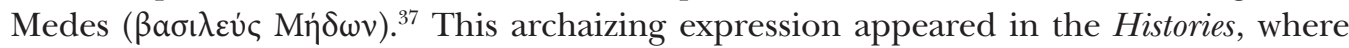
Herodotus used this title for Cyrus the Great, who built his empire by first conquering the Medes, then Croesus' realm, the Lydian Empire. ${ }^{38}$ Therefore, the archaizing title of Chosroes hints at not only the king, but his intermittent status as well.

During the description of the envoy to Chosroes, Procopius used a similar method apropos the description of Vitigis' royal title. In his work, Procopius mentioned all Ostrogothic monarchs of Italy from Theodoric to Theia. However, their titles as kings are presented slightly differently. Theodoric is simply the king $\left.(\beta a \sigma \iota \lambda \varepsilon v)^{39}\right)^{39}$ or the ruler

34 Cens. 22, 16, Suet. Aug. 31.2.

35 Procop. Goth. 1.24.28-30.

36 The first embassy went to the Lombards, offering money to encourage them into an alliance, however, the envoys realized that they were the ally of the emperor.

37 Procop. Goth. 2.22.17. Procopius frequently use the word Medes as a synonym on the Persians. However, their kings always appeared in his work as the king of the Persians, even in those speeches that Procopius attributed the certain envoys. E.g. Procop. Pers. 1.2.7; 1.2.8 (Yazdgird, the king of the Persians), 1.2.11 (Bahram, the king of the Persians), 1.3.1 (Peroz, the king of the Persians), 1.5.10 (Pakourios was king of the Persians), 1.12.3 ([Kavad], king of the Persians), 1.21.22 (Chosroes king of the Persians), 1.21.24 ([Chosroes] king of the Persians), 1.22.1 ([Chosroes] king of the Persians), 2.1.12 (Chosroes king of the Persians), 2.3.31 (Chosroes king of the Persians), 2.9.12 (Chosroes became king of the Persians), Procop. Goth. 3.32.2 (Chosroes, the king of the Persians), 4.4.5 (Chosroes king of the Persians), 4.11.24 ([Chosroes] king of the Persians), 4.14.6 ([Chosroes] king of the Persians), 4.26.13 ([Chosroes] king of the Persians).

38 Hdt. 1.73.1-2, 1.129.1-4. Astyages (585-550 BC), the last king of the Median Empire, was dethroned in 550 BCE by Cyrus the Great. Not long after Tomyris, the queen of the Massagetae sent a herald to him with this message with the following form of address: “ $\tilde{\omega} \beta a \sigma \iota \lambda \varepsilon \tilde{v}$ Mrj $\delta \omega v ”(H d t .1 .206 .1)$. 
(äpxov) of the Goths, ${ }^{40}$ while Theodahad is referred to as the Totila ruler of the Goths. ${ }^{41}$ Hildebad came to power over the Goths as well as Theia. ${ }^{42}$ Athalaric, Amalasuntha, Erarius, and Aligern are given no exact title. The reign of Vitigis, in contrast, concerns not only the Goths, but also the Italians. Procopius mentioned him using the title King of

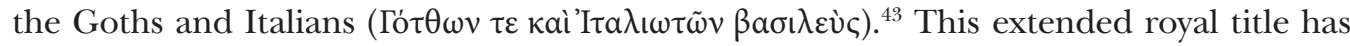
similarities with the title of Croesus, who appeared in the Histories as King of Lydia and other nations ( $\Lambda v \delta \tilde{\omega} v \tau \varepsilon$ kaì ă $\lambda \lambda \omega v \varepsilon \dot{\varepsilon} \theta v \varepsilon \dot{\varepsilon} \omega v \beta a \sigma ı \lambda \varepsilon v \dot{\varsigma}){ }^{44}$

After the elder's council, Vitigis sent a letter through two priests to Ctesiphon that strongly influenced Chosroes; ${ }^{45}$ however, Procopius did not mention this letter in his description of the diplomatic meeting. ${ }^{46}$ The Wars mentions more than two dozen envoys that carried letters to different recipients. ${ }^{47}$ When Procopius recites the contents of a letter, before or after the quotation, he always mentions that this was indeed a letter $(\gamma \rho \dot{\alpha} \mu \mu \alpha \tau \alpha)$ and not a verbal message. ${ }^{48}$ However, in the case of Vitigis's envoy to Chosroes, there is no mention of the letter. He also uses a different closing formula, which again stresses the similarities between Croesus and Vitigis. According to Procopius, when Chosroes heard the speech of the envoys, it seemed to him that Vitigis advised well. through this Procopius emphasized the importance of Vitigis himself as if he were present. A likely explanation for this is that Procopius again used Herodotus' Histories, where the good advice is an essential part of the conversation between Croesus and Cyrus on the ruin of Sardis. ${ }^{49}$

The timeframe also stresses the similarities between Croesus and Vitigis, because both kings fell in the third year after the oracle. According to Herodotus, even Loxias could not deflect the Fates; however, he did accomplish his wish for Croesus when he delayed the capture of Sardis for three years. He let Croesus know that although Cyrus captured him in Sardis, it happened three years later than the destined hour, and that Croesus was wrong in his understanding of the real meaning of the oracle. Loxias declared to him that if he led an army against the Persians, he would destroy a great empire, but this empire was his own. ${ }^{50}$ Similarly, in Rome, the patricians had an incorrect understanding

40 Procop. Goth. 1.24.22.

41 Procop. Goth. 1.13.14 (Theodahad), 1.24 .32 (Totila).

42 Procop. Goth. 2.30.17 (Hildebad), Procop. Goth. 4.34 .9 (Theia).

43 Procop. Pers. 2.2.4; 2.4.13.

44 Hdt. 1.69.2.

45 Procop. Goth. 2.22.20.

46 Procop. Goth. 2.2.1-12.

47 Procop. Pers. 1.11.6-9, 1.22.11, 2.4.16-25, 2.13.1, 2.16.5-15, 2.20.21-24, 2.20.25-28, 2.28.39, Procop. Vand. 1.16.12-15, 1.25.10-19, Procop. Vand. 2.14.41, 2.22.6-10, Procop. Goth. 1.3.16-19, 1.3.19-27, 1.4.22, 1.5.8-10, 1. 6.15-22, 1.6.22-26, 1.24.1-18, 2.16.14-17, 2.18.27-28, 2.22.20, 2.24.3, 2.24.7-10, 2.26.4-14, 2.26.15, 3.9.5, 3.9.6-19, 3.10.15, 3.12.3-11, 3.13.19, 3.21.19-25, 3.22.7-16, 4.19.9-22.

48 E.g. Procop. Goth. 1, 6.15-22. In the case of Theodahad's envoy, Procopius started the quotation that the contents of the letter were as follows and closed it properly when he emphasized that this was a letter.

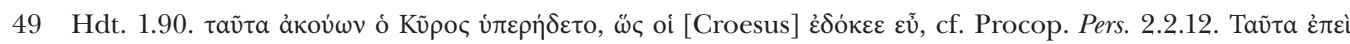

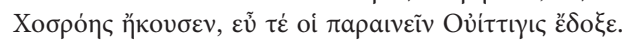

50 Hdt. 1.91.2-3. 
of the oracle. The month of Quintilis reflected the fifth king of the Ostrogoths, and not July. Justinian's army seized Ravenna three years later than the destined hour. That was when the patricians consulted the Book of Sybil, in 537.

\section{Getic}

The oracle's second accentual element is the ethnonym Getic, which appeared as a synonym for the Goths in the works of the Early Medieval authors. The mention of this world in this form is rare; however, according to the sophist Philostratus, Dio Chrysostom

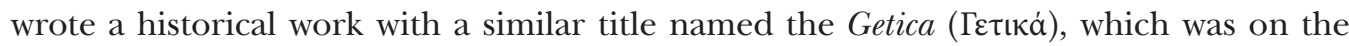

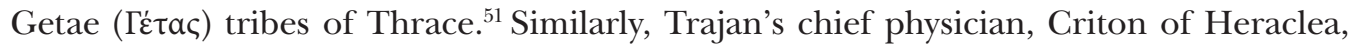
wrote a work called the Getica (Гєєıкá) about the history of Daco-Getae. ${ }^{52}$ This trend continued in the 6th century with the Getica, in which Jordanes transmitted the earlier historical narratives of the Getae to both Gothic nations. ${ }^{53}$ His contemporary, John the

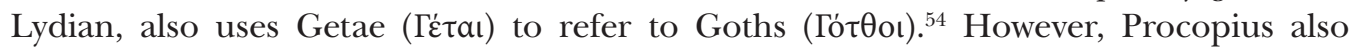
claimed that the Goths are a Getic (Гєนเкòv) race, and that there were some authors who called the Goths, Visigoths, and other nations Getic. ${ }^{55}$ Therefore, during the 5 th and 6 th centuries, historians and ethnographers used the ethnonym Getic/Getae-along with other nations-to refer to the Ostrogoths and Visigoths as a generic term.

In the entire corpus, Procopius uses the ethnonym Getic only in two places, both of which can be found in the Wars. Through the use of this ethnonym, the emphasizes the connection between the Ostrogoths and Visigoths. It appears during the description of the two Gothic sieges of Rome. The first appearance of the Getic is in the description of 410, the prologue to the sack of Rome. Only a few lines before Procopius discusses Alaric's siege of Rome, he gives a list of those nations who lived in the territory of the Empire at the time of Honorius. Among them were the two Gothic nations, who were once called Getic. ${ }^{56}$ Procopius begins this description only after his introduction on how Alaric led the Visigoths from Thracia against the city, while he closes the chapter with a description of how the Ostrogoths conquest began moving west from Thracia. ${ }^{57}$ The second appearance of the Getic is in 537, during Vitigis's siege of Rome, when the patricians consulted with the Sibyls and attempted to predict the end of the war. ${ }^{58}$ Alaric's siege was successful while Vitigis's failed. Therefore it seems that Procopius uses the eth-

51 Philostr. VS 1.7.

52 Bennett (2001: p. 91).

53 Iord. Get.

54 Lyd. Mens. 4.132; Lyd. Mag. 3.55-56.

55 Procop. Goth. 1.24.30, Procop. Vand. 1.2.2.

56 Procop. Vand. 1.2.1-2.

57 Procop. Vand. 1.2.7, cf. 1.2.40.

58 Procop. Goth. 1.24.28-29. 
nonym Getic to frame the western history of the Goths starting with the Visigoth Alaric in 410 and ending with Ostrogoth Vitigis in 537.

The most notable act of 410 was the abduction of Galla Placidia, who became Alaric's captive. Her well-known captivity resulted in a great echo from many authors including Procopius's contemporaries Jordanes and Marcellinus Comes. However, Procopius does not mention Placidia's abduction, her intermarriage with Athaulf, or her homecoming several years later.$^{59}$ Instead, he incorporates the fate of Honorius' sister in those archaic ethnonyms that he mentioned at the beginning of the chapter. All three, the Sauromatai, Melanchlainai, and Getae, are known from Herodotus. ${ }^{60}$ According to him, the Sauromatai were born from the intermarriage of Scythian men and Amazon women. ${ }^{61}$ Based on his legends, the ancient authors defined the Getae as the offspring of the Sauromatai and Melanchlainai. ${ }^{62}$ Therefore, each represents an interracial relationship that continued with Athaulf and Galla Placidia after 410.

The prologue of the sack of Rome in the Wars is similar to the Histories' introduction. In the sentence preceding the description of Alaric's entrance to Rome, Procopius emphasizes that the peoples under Honorius differed only in their names, but in deeds they were the same. ${ }^{63}$ In his work, the Histories or the so-called Graeco-Persian Wars, Herodotus states that among others, he knows that those deeds, resulted in their waging war on each other. However, his story begins not with the Persians, but with the Phoenicians. According to Herodotus, one time when the Phoenicians were trading in Argos, Io, the king's daughter whom they had abducted, appeared on their ship. A generation later, we still do not find Persians, but rather Trojans, when Paris abducted Helen. ${ }^{64}$ Moreover, Herodotus knows that among these barbarians, the first known person was not a Persian, but the Lydian Croesus, ${ }^{65}$ who lost his war against the Persians and finally became Persian as a subject of Cyrus. ${ }^{66}$ His fall, however, was rooted five generations earlier, when his ancestor Gyges sexually harassed Candaules' wife, Nyssia. ${ }^{67}$

There is a vast temporal gap between Rome's two sieges as well as the reign of Athaulf and Vitigis; however, this did not strain the connection between them. Vitigis's fifth predecessor was Theodoric who, according to our sources, did not commit any harassment against any women. According to Procopius, after his election, Vitigis's first action was to depart from Rome to Ravenna, where he forced Matasuntha into marriage because he believed that a tie with Theodoric's family could make his reign more stable. ${ }^{68}$ Vitigis was

59 Iord. Get. 159; Marcell. auct. chron. II, p. 70.8. Cf. Procop. Vand. 1.2.1-40.

60 Hdt. 4.21,57,102,110,116-117,119-120,122-123,128,136 (Sauromatai), Hdt. 4.20,100-102,107,119,125 (Melanchlainai), Hdt. 4.93-94,96-97,118,5.3-4 (Getae).

61 Hdt. 4.110-116.

62 Steinacher (2013: pp. 339-440).

63 Procop. Vand. 1.2.3.

64 Hdt. 1.1.1-4, 1.3.1-2.

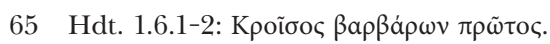

66 Hdt. 1.88-89.

67 Hdt. 1.7-13.

68 Procop. Goth. 1.11.27. 
the fifth king of the Ostrogoths, however, his legitimacy was based on Theodoric's granddaughter, Matasuntha. In 540, he further underlined the role of this woman through the portrayal that Vitigis did not fall alone, but with her. Accordingly, Procopius treated them side by side. According to him, Justinian was pleased to see them and marveled $(\dot{\varepsilon} \theta a \dot{\mu} \mu \alpha \sigma \varepsilon)$ at both the beauty and physical stature of the barbarian throng. ${ }^{69}$ This is an

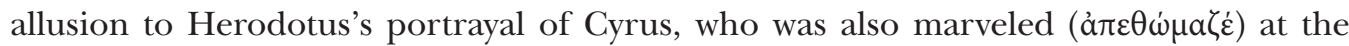
physical appearance of Croesus. ${ }^{70}$ Thus the process that started with Alaric ended with Theodoric's family.

Theodoric did not lack female family members; he used them to strengthen his connection with other peoples. As soon as he stabilized his position in Italy, Theodoric gave his daughter Theodegotha to Alaric II, the great-grandson of Alaric I. This marriage united not only the two Gothic clans, the Amali and the Balhi ${ }^{71}$ but uplifted him into a third-degree family relationship with Alaric I. When Clovis killed his son-in-law in the Battle of Vouillé (507), Theodoric became regent over the Visigoths after rescuing his young grandson Amalaric. In 515, he further strengthened this connection when he made the Visigothic Amal Eutharic the husband of his other daughter, Amalasuintha. Nonetheless, Theodoric's intention to integrate the two Gothic peoples never took place because after his death both of his grandsons, Amalaric and Athalaric, took over the governments as independent rulers. However, after the murder of Theodegotha's son in 531 and the death of Amalasuintha's son Athalaric, Matasuntha became the last living heir of Theodoric and the only royalty who was five generations removed from Alaric I, through her grandfather.

\section{$* * *$}

This study has identified that both the circumstances of prognostication and the words 'quintilis' and 'Getic' referred to the Delphic oracle of Croesus that predicted his fall in the Histories. Therefore, through several allusions to Herodotus, Procopius drew parallels between the overthrowing of Vitigis and Croesus. The second major finding was that the ethnonym Getic framed the history of the two Gothic nations through the sieges of Rome in 410 and 537. Through this framework, Procopius emphasized that although their history began with Alaric, who committed the original crime, Vitigis and his wife were the ones who atoned for his $\sin$ in 540 . Vitigis was the fifth successor of Theodoric's realm; however, his legitimacy was based on Matasuntha, who was the last direct descendant of Theodoric and the only royalty who was five familial steps from Alaric. On the grounds of this paper, the Oracle should be read in 537 and now with the understanding that "the fifth ... as king nothing Goth longer" means a decisive victory over the Gothic people, at least in Byzantine's point of view.

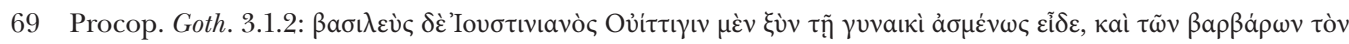

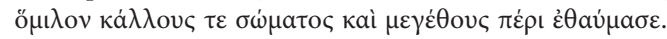

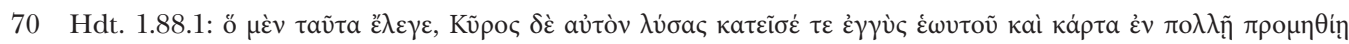

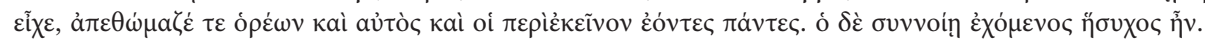

71 Wolfram (1990: p. 309). 
These results were based on the thesis of Reinhard Wenskus, who wrote that the inheritance of Germanic tribes was carried by the stirps regia, whose destiny coexisted with the fate of their own people. ${ }^{72}$ This narrow group suffered heavy casualties during the overthrow of Vitigis and Matasuntha. After this date, Procopius mentioned a Goth, Goar, who was in constant rebellion against his fate, ${ }^{73}$ but as Pythia enunciated in Herodotus' work, "No one may escape his fate, not even a god." 74 In addition to the results of this research, this paper has brought to light many questions in need of further investigation. One such investigation could be an extensive analysis of the usage of archaic ethnonyms and other titles in Procopius's work, which possibly will reveal additional consistencies. Furthermore, based on Procopius's framing technique and in the reflection of Herodotean allusions, it is possible that the triumphal column of Justinian that was erected in 543 is based not only on the victory over the Persians, but on the victory over the Amal dynasty as well.

\section{Bibliography}

Bennett, J. (2001). Trajan: Optimus Princeps (2nd ed.). London: Routledge.

Bury, J. B. (1896). Nugae Procopianae. Hermathena, 9(22), 358-361.

Gillmeister, A. (2015). Cultural paraphrase in Roman religion in the age of Augustus. The case of the Sibyl and the Sibylline books. Acta Antiqua Academiae Scientiarum Hungaricae, 55(1-4), 211-222.

Keskiaho, J. (2013). Re-visiting the Libri Sibyllini: Some Remarks on Their Nature in Roman Legend and Experience. In M. Kajava (Ed.), Studies in Ancient Oracles and Divination. Roma: Institutum Romanum Finlandiae.

Kim, L. Y. (2010). Homer between History and Fiction in Imperial Greek Literature. Cambridge: Cambridge University Press.

Morrison, J. V. (1997). Kerostasia, The Dictates of Fate, and the Will of Zeus in the Iliad. Arethusa, 30(2), 276-296.

Pratt, L. H. (1993). Lying and Poetry from Homer to Pindar: Falsehood and Deception in Archaic Greek Poetics. Ann Arbor: University of Michigan.

Steinacher, R. (2013). Who Is the Barbarian? Considerations on the Vandal Royal Title. In W. Pohl (Ed.), Post-Roman Transitions: Christian and Barbarian Identities in the Early Medieval West (pp. 437-485). Turnhout: Brepols.

Wenskus, R. (1961). Stammesbildung und Verfassung. Das Werden der frühmittelalterlichen Gentes. Köln: Böhlau.

Wolfram, H. (1990). History of the Goths (2nd ed.). Berkeley - Los Angeles - London: University of California Press.

72 Wenskus (1961).

73 Procop. Goth. 4.27.5-6.

74 Hdt. 1.91.1. 
Tamás Kovács, PhD / kovacstamas@hist.u-szeged.hu

Department of Medieval Studies

University of Szeged, Faculty of Humanities and Social Sciences

Egyetem utca 2, 6720 Szeged, Hungary 